\title{
A survey on the knowledge, attitude and acceptance of male sterilzation among men in Ogbomoso, South West Nigeria
}

\author{
*Ogunlaja O.A. ${ }^{1}$, Akinola S.E. ${ }^{1}$, Aworinde O.O. ${ }^{1}$, Ogunlaja I.P. ${ }^{2}$, Bojuwoye M.O. ${ }^{3}$
}

\begin{abstract}
Background: Traditionally, majority of the family planning services and campaigns focus on women without much consideration given to their male partners. In our society, there is bias, myth and misconception about vasectomy, this has resulted in a significant reduction in the willingness of men to seek vasectomy as a means of family planning. This study aims to identify the level of awareness and acceptance of male sterilization among men in Ogbomoso, south west Nigeria.
\end{abstract}

Methods: This study was a cross sectional survey carried out among men in Ogbomoso, participation was voluntary and three hundred men had the questionnaires complete and suitable for analysis.

Result: This study revealed a high level of awareness of family planning methods among men in Ogbomoso. However, less than half of these men agreed that men should be involved in family planning despite a higher number of the respondents being aware of vasectomy as a means of contraception. The common reasons for not accepting of vasectomy varied from preference for other methods of contraception, cultural taboos, religious sentiments, similarity to castration, fear for surgery and surgical complications.

Conclusion: Renewed effort has to be made which will be aimed at improving the level of information about vasectomy in the public domain especially by the media and health care workers. This effort should also be targeted at religious organizations, clerics and traditional institutions this is because most of these misconceptions have deep rooted religious and cultural sentiments. This can also be achieved by ensuring synergy between government, non governmental organizations, advocacy groups, traditional and religious rulers.

Keywords: knowledge, attitude, acceptance, vasectomy, male sterilization.

*Corresponding Author

Ogunlaja O.A.

http://orcid.org/0000-0001-8905-132X

Email:1ajamuyiwa@yahoo.com

${ }^{1}$ Department of Obstetrics and Gynaecology, Bowen University Teaching Hospital, Ogbomoso, Nigeria

${ }^{2}$ Department of Obstetrics and Gynaecology, General Hospital, Ilorin, Nigeria

${ }^{3}$ Department of Medicine, University of Ilorin Teaching Hospital, Ilorin, Nigeria

Research Journal of Health Sciences subscribed to terms and conditions of Open Access publication. Articles are distributed under the terms of Creative Commons Licence (CC BY-NC-ND 4.0). (http://creativecommons.org/licences/by-nc-nd/4.0).

http://dx.doi.org/10.4314/rejhs.v5i4.4 


\title{
Une enquête sur la connaissance, l'attitude et l'acceptation de la stérilisation masculine chez les hommes à Ogbomoso, au sud-ouest du Nigeria
}

\author{
Ogunlaja O.A.1, Akinola S.E.1, Aworinde O.O.1, Ogunlaja I.P.2, Bojuwoye M.O.3
}

\begin{abstract}
Resume
Objectif: Traditionnellement, la majorité des services et des campagnes de planification familiale sont axés sur les femmes, sans considération pour leurs partenaires masculins. Dans notre société, il y a des préjugés, des mythes et des idées fausses à propos de la vasectomie, ce qui a entraîné une réduction significative de la volonté des hommes à rechercher la vasectomie comme moyen de planification familiale. Cette étude vise à identifier le niveau de sensibilisation et d'acceptation de la stérilisation masculine chez les hommes à Ogbomoso, au sud-ouest du Nigeria.
\end{abstract}

Méthodes: Cette étude était une enquête transversale réalisée chez des hommes à Ogbomoso, la participation était volontaire et trois cent hommes avaient rempli les questionnaires et pouvaient être analysés.

Résultat: Cette étude a révélé un haut niveau de sensibilisation aux méthodes de planification familiale chez les hommes à Ogbomoso. Cependant, moins de la moitié de ces hommes étaient d'accord pour dire que les hommes devraient être impliqués dans la planification familiale, même si un plus grand nombre de répondants étaient conscients de la vasectomie comme moyen de contraception. Les raisons communes pour ne pas accepter la vasectomie variaient de la préférence pour d'autres méthodes de contraception, les tabous culturels, les sentiments religieux, la similarité avec la castration, la peur de la chirurgie et les complications chirurgicales.

Conclusion: Il faut redoubler d'efforts pour améliorer le niveau d'information sur la vasectomie dans le domaine public, en particulier par les médias et les travailleurs de la santé. Cet effort devrait également viser les organisations religieuses, les clercs et les institutions traditionnelles, car la plupart de ces idées fausses ont des racines religieuses et culturelles profondément enracinées. Cela peut également être réalisé en assurant une synergie entre le gouvernement, les organisations non gouvernementales, les groupes de défense, les chefs traditionnels et religieux.

Mots-clés: connaissance, attitude, acceptation, vasectomie, stérilisation masculine.

*Corresponding Author

Ogunlaja O.A.

http://orcid.org/0000-0001-8905-132X

Email:1ajamuyiwa@yahoo.com

${ }^{1}$ Department of Obstetrics and Gynaecology, Bowen University Teaching Hospital, Ogbomoso, Nigeria

${ }^{2}$ Department of Obstetrics and Gynaecology, General Hospital, Ilorin, Nigeria

${ }^{3}$ Department of Medicine, University of Ilorin Teaching Hospital, Ilorin, Nigeria

Research Journal of Health Sciences subscribed to terms and conditions of Open Access publication. Articles are distributed under the terms of Creative Commons Licence (CC BY-NC-ND 4.0). (http://creativecommons.org/licences/by-nc-nd/4.0).

http://dx.doi.org/10.4314/rejhs.v5i4.4 


\section{INTRODUCTION}

Family planning is the practice of controlling the number of children in a family and the intervals between their births (1). In our society the female partners are more willing to per take in the process of family planning than their male partners, this may be because the burden of child bearing, rearing and the attendant house hold chores are seen primarily as the role of the woman (1). Traditionally, majority of the family planning services and campaigns were focused on women without much consideration given to their male partners. Research in Africa have revealed that involvement of men and obtaining support from them has been a challenge despite the fact that most decisions are made by them (2).

There are different methods used for family planning, these methods ranges from the natural methods which involves exploiting the physiology of reproduction to those which involves the use of contraceptive agents like intrauterine contraceptive device, hormonal agents etc.

The practice of permanent contraception varies from one part of the world to the other. Vasectomy as a permanent method of contraception has a high acceptance rate in developed countries like the United States of America and Australia $(3,4)$. However, vasectomy is still not widely accepted in many African countries including Nigeria $(5,6)$. In Nigeria, men are unwilling to have vasectomy as a result of its permanent nature hence resulting in its low acceptance in Nigeria. Ignorance, have been recognized as a major reason, some of the common myths and misconceptions which are as a result of ignorance includes the belief that it causes impotence, ejaculatory failure, weight gain, and its equation with castration $(7,8)$.

Over the years there has been tremendous efforts at improving knowledge of vasectomy among men and improving on the techniques of performing the procedure to increase its acceptance among the population (9). Vasectomy can either be done surgically or non surgically (No-scapel technique). Surgically, vasectomy is performed in two separate steps: exposing some portions of the vas deferens out of the scrotum a step known as isolation, and in the next step, occluding the vas. The other method of performing vasectomy is the No-scalpel vasectomy (NSV) technique, it is used in the isolation of the vas deferens in the United States, it is becoming an increasingly popular method among physicians also a choice for the developing countries (10-14). The notable advantages includes a lower risk of hematomas, less bleeding and pain, lower risk of infections and less operating time (11-13).

Literature search reveals paucity of data on the level of knowledge, attitude and acceptance of male contraception among men in Ogbomoso, South west Nigeria. This study aims to investigate the level of awareness and acceptance of male sterilization among men in Ogbomoso, south west Nigeria.

\section{METHODOLOGY}

This study was a cross sectional survey carried out using questionnaires on men in Ogbomoso. These questionnaires were self-administered and had been pre-tested among randomly selected adult male staff members of Bowen University Teaching Hospital, Ogbomoso. The questionnaire had three sections: Biodata (Marital status, age, tribe, religion, and education level), questions on knowledge on vasectomy and acceptance of vasectomy as a family planning method. Participation in the study was voluntary and subjects were selected randomly by balloting. Ethical approval was sought prior to the conduct of the study. Confidentiality of the respondents was ensured. Analysis of data was done using SPSS 20.

\section{RESULTS}

Out of a total of 340 questionnaires were administered only 300 were suitable for analysis. Majority $129(43 \%)$ of the respondents were between the ages of 25-35 years, more than half of the respondents $159(53.0 \%)$ were married. Formal education was obtained by 299 of the 300 responders accounting for $99.4 \%$ with tertiary education being the highest at $282(94 \%)$ out of 300 . When religion and ethnicity of the responders were analyzed; the Christianity and the Yoruba ethnic group accounted for a significant majority of the respondents at $274(91.3 \%)$ and $262(87.3 \%)$ respectively.(Table 1)

Concerning the level of knowledge of family planning, 277(92.3\%) had an idea of family planning methods; however, only $137(45.7 \%)$ of the respondents agreed that men should be involved in family planning. Two hundred and thirty seven $(79.3 \%)$ of the responders have heard about vasectomy with the first source of information as follows; mass media 113(45.9\%), health workers 98(39.8\%) 
and family members and friends 35(14.2\%).It was observed that only $218(89.3 \%)$ of the respondents had the prior knowledge that vasectomy was carried out in Nigeria while the others considered it not done in Nigeria.

When acceptance of vasectomy was considered, only ninety two (30.7\%) respondents were willing to have vasectomy, another six $(0.02 \%)$ respondents were indifferent, while the others i.e two hundred and two respondents were unwilling to have vasectomy. (Figure 1)

Among the two hundred and two respondents having knowledge of vasectomy attributed their reason for not accepting of vasectomy as a method of contraception for the following reasons; preference for other methods of contraception 42(20.8\%), cultural taboos $17(8.4 \%)$, religious sentiments $13(6.4 \%)$, similarity to castration $9(4.4 \%)$, fear for surgery and surgical complications $8(4.0 \%)$.

\section{DISCUSSION}

The findings from this study revealed a high level of awareness of family planning methods among men in Ogbomoso. However, less than half of these men agreed that men should be involved in family planning despite a higher number of the respondents being aware of vasectomy as a means of contraception. The reason for this may be due to the various myths, misconceptions and bias associated with the practice of vasectomy $(7,8,15)$. Some of the common myths and misconceptions include the belief that vasectomy causes impotence, ejaculatory failure, weight gain, and its equation with castration $(7,8)$.

This myth, misconceptions and bias are probably due to poor knowledge and subsequent dissemination of information by individuals with incomplete understanding of vasectomy as a method of family planning. A previous study revealed that the vast majority of doctors were convinced that the average Nigerian male will not accept vasectomy when indicated while more than three-fifth consider bilateral tubal ligation a more appropriate option for permanent contraception in our setting (15). The bias to believe that Nigerian males will not accept vasectomy is clearly not borne out of the experience of counselling males for vasectomy since most of the Doctors admitted to not counselling often for vasectomy $(15,16,17)$.

It has been shown that with proper counseling techniques and right information about vasectomy the rate of its uptake as a contraceptive method is likely to increase (18). With the notable observations in our study, it can be inferred that a large amount of the male population is aware of vasectomy as a means of family planning, however, many are unwilling to get it done due to reasons like preference for other methods, cultural taboos, religious sentiments, similarity to castration and fear for surgery and surgical complications. It is pertinent to note that many of this reasons are probably due to poor or wrong information in the domain of these men by their various informants which makes them unwilling to have vasectomy done as a means of contraception. To correct this anomaly, effort has to be aimed at improving the depth of correct information about vasectomy in the public domain by the media and health care workers. This can be done through a proper reorientation of the individuals involved in health information management especially as it concerns vasectomy and family planning as a whole.

This effort should also be targeted to reach religious organizations, clerics and traditional rulers since some of these misconceptions had deep rooted religious and cultural sentiments. The role of men in family planning should also be reemphasized through advocacy, campaigns and other awareness program.

Health workers and health care workers in training need to be trained and retrained from time to time in order for them to be well equipped with the necessary counseling skills required to improve the acceptance of vasectomy due to the existing bias against vasectomy as an option of contraception during counseling for family planning. This goal can be achieved by ensuring a synergy between government, non-governmental organizations, traditional rulers, clerics, policy makers and advocacy groups.

Conflict of interest: The authors declare no conflicts of interest.

\section{REFERENCES}

1. Okedeji FO. Attitude, knowledge and practice of family planning among married women in the city of Ibadan. West Africa Method Journal 2003;13(6):213-215

2. Odimegwu CO. Family planning attitudes and use in Nigeria: A factor analysis International Family Planning Perspectives, 2009; 25 (2): 8691.

3. Holden CA, Mclachlan RI, Cumming R, Wittert G, Handelsman D J, de Kretser D M, et al. Sexual activity, fertility and contraceptive use in middle 
aged and older men; Men in Australia, Telephone survey (MATES) Hum Reprod. 2005; 20 (12):3429-3434.

4. Barone M A, Johnson CH, Luick MA, Teutonico DL, Magnani RJ. Characteristics of Men receiving vasectomy in the United States 1998-1999. Perspect Sex Reprod Health. 2004;36(1):27-33.

5. Bunce A, Guest G, Searing H, Frajzyngier V, Riwa P, Kanama J, et al. Factors affecting vasectomy acceptability in Tanzania. Int Fam Plan Perspect. 2007;33(1):13-21.

6. Dibaba A. Rural men and their attitude towards vasectomy as a means of contraception in Ethiopia. Trop Doct. 2001;31 (2):100-102.

7. Odu OO, Ijadunola KT, Komolafe JO, Adebimpe WT. Men's knowledge of and attitude with respect to family planning in a suburban Nigerian Community. Niger J Med. 2006; 15 (3):260-265.

8. Okpere EE. Contraceptive knowledge, attitudes and behavior among Nigerian Males: Benin City and Udo. A survey sponsored by the office of population, United States Agency for International Development. 1988. [10 December 2009]. Available from: http://www.popline.org.

9. Li SQ, Goldstein M, Zhu J, Huber D: The noscalpel vasectomy. J Urol 1991;145:341-4.

10. Haws JM, Morgan GT, Pollack AE, Koonin LM, Magnani RJ, Gargiullo PM.Clinical aspects of vasectomies performed in the United States in 1995. Urology 1998;52(4):685-91.

11. Black T, Francome C: Comparison of Marie Stopes scalpel and electrocautery no-scalpel vasectomy techniques. J Fam Plann Reprod Health Care 2003, 29(2):32-4.

12. Kumar V, Kaza RM, Singh I, Singhal S, Kumaran V. An evaluation of the no-scalpel vasectomy technique. BJU Int 1999, 83(3):283-4.

13. Nirapathpongporn A, Huber DH, Krieger JN. No-scalpel vasectomy at the King's birthday vasectomy festival. Lancet 1990 ; 335(8694):894-5.

14. Xu B, Feng H, Liu XZ. No-scalpel vasectomy training in China. Adv Contracept Deliv Syst 1993, 9(1):1-8.

15. Ebeigbe $\mathrm{PN}$, Igberase $\mathrm{GO}$, Eigbefoh J. Vasectomy: a survey of attitudes, counseling patterns and acceptance among Nigerian resident gynaecologists. Ghana Med. J. 2011 Sep;45(3):101-104

16. Owopetu C, Chukwuma S, Nwozichi C. Knowledge and attitude of men about vasectomy as a method of family planning among married men working in Babcock University, Ogun State, Nigeria. Int. J of Nurs. and Midwifer. 7(3),3035,2014. DOI:10.5897/IJNM2014.0157

17. Onasoga OA,Edoni EER, Ekanem J. Knowledge and attitude of men towards. vasectomy as a family planning method in Edo state. J. Res. Nurs. Midwifery. 2013; 2(1):13-21.

18. Muhondwa H, Rutenberg N. Population Council, Africa Operations Research and Technical
Assistance project. USAID; 1997. [7 December 2009]. Effects of the Vasectomy Promotion Project on Knowledge, attitudes, and behaviour among men in Dares Salaam, Tanzania. Available $\begin{array}{lllll}\mathrm{f} & \mathrm{r} & \mathrm{o} & \mathrm{m}\end{array}$ http://pdf.usaid.gov/pdf_docs/PNACE476.pdf. 
Table 1: Socio-demographic variables of respondents.

\begin{tabular}{|c|c|c|c|}
\hline Variable & Description & Frequency & Percentage \\
\hline Age in years & $\begin{array}{l}15-24 \\
25-34 \\
35-44 \\
45-54 \\
55-64 \\
>65\end{array}$ & $\begin{array}{r}48 \\
129 \\
75 \\
35 \\
10 \\
3\end{array}$ & $\begin{array}{r}16.0 \\
43.0 \\
25.0 \\
11.7 \\
3.3 \\
1.0\end{array}$ \\
\hline Marital status & $\begin{array}{l}\text { Not married } \\
\text { Married } \\
\text { Divorced }\end{array}$ & $\begin{array}{r}126 \\
159 \\
15\end{array}$ & $\begin{array}{r}42.0 \\
53.0 \\
5.0\end{array}$ \\
\hline Level of Education & $\begin{array}{l}\text { No formal } \\
\text { education } \\
\text { Primary } \\
\text { Secondary } \\
\text { Tertiary }\end{array}$ & $\begin{array}{r}1 \\
1 \\
16 \\
282\end{array}$ & $\begin{array}{r}0.3 \\
0.3 \\
5.4 \\
94.0\end{array}$ \\
\hline Tribe & $\begin{array}{l}\text { Yoruba } \\
\text { Igbo } \\
\text { Hausa } \\
\text { Others }\end{array}$ & $\begin{array}{r}262 \\
20 \\
3 \\
15\end{array}$ & $\begin{array}{r}87.3 \\
6.7 \\
1.0 \\
5.0\end{array}$ \\
\hline Religion & $\begin{array}{l}\text { Christianity } \\
\text { Islam } \\
\text { Traditional } \\
\text { religion }\end{array}$ & $\begin{array}{r}274 \\
24 \\
2\end{array}$ & $\begin{array}{r}91.3 \\
8.0 \\
0.6\end{array}$ \\
\hline
\end{tabular}



Figure 1 Acceptance of vasectomy among male respondents. 